\title{
NOTAS SOBRE O GENERO LEPTOPYRGOTA HENDEL, COM DESCRIÇÃO DE VINTE E UMA NOVAS ESPÉCIES DO BRASIL (DIPTERA, PYRGOTIDAE)
}

Nelson Bernardi ${ }^{1}$

\begin{abstract}
Notes and comments on the Neotropical genus Leptopyrgota Hendel are presented. The following Brazilian species are described as new: apposita, celeriuscula, acco. lens, quaerens, ensifera, definienda, cocta, andrei, marci, sarae, juniae, liae, isabelae, gracilenta, flavipes, lenkoi, brevipennis, tibialis, minensis, caelifera, hesterna.

A última contribuição mais ou menos extensa ao conhecimento dos Pyrgotidae da Região Neotropical fol a revisão parcial publicada por AZEĖL (1956), à qual devemos acrescentar o catálogo de STEYSKAL (1967). A esses dois textos deve-se recorrer para informações pertinentes à bibliografia e à distribuição geográfica.

Neste trabalho, estudo o maior dos gêneros neotropicais. Apresento algumas notas e comentários acerca de espécies já divulgadas pela literatura e descrevo vinte e uma novas espécies do Brasil. Todo o material aqui referido pertence à Coleção do Museu de Zoologia da Universidade de São Paulo. Pela oportunidade de estudar esse material, bem como pelo acesso à bibliografia pertinente, muito agradeço ao Dr. Nelson Papavero.
\end{abstract}

\section{Leptopyrgota albitarsis Aczél}

Material. BRASIL. Minas Gerais: Serra do Caraça, 1380 m, 1 q. São Paulo: Barueri, 1 o; Campos do Jordðo, Eugénio Lefevre, 1200 m, 3 ઠ , 2 \%.

\section{Leptopyrgota costalimai Aczél}

A descrição original desta espécie teve por base uma fêmea do Corcovado, Rio de Janeiro. Em comparação com essa descrição, anotamos algo sobre o macho. As marcas da cabeça são mais escuras que as da fêmea e, nos dois exemplares em mãos, são um pouco diferentes. As faixas da fronte descem pelos lados das antenas, são muito finas nas bordas da placa mesofacial, embaixo alargam-se novamente e confluem com a mancha localizada abaixo dos olhos. O "Y" invertido da placa mesocafial é um pouco mais nítido e num dos exemplares tem os braços laterais bem mais largos e quase confluentes, formando, por conseguinte, um triângulo quase completo na base. A coloração do abdome é diferente. A base do sintergito é clara, da mesma cor do tórax, seu segundo terço já é mais escuro, castanho, e sua parte final e os tergitos restantes são castanhos muito escuros, quase negros.

1. Departamento de Zoologia, Instituto de Biociências, Universidade Estadual Paulista, 18610 Botucatu, São Paulo. 
Material. BRASIL. São Paulo: Barueri, 2 ๆ; Salesópolis, Estação Biológica de Boracéa, 1 ơ, 3 \%; săo Paulo, 1 రั.

\section{Leptopyrgota mehelyi Aczél}

Nenhum dos exemplares que menciono abaixo possui o escurecimento ânteroapical na asa. A não ser num macho (São Paulo, SP), em que o padrão da coloração cefálica e torácica é muito nítido, com fundo amarelo claro contrastando fortemente com as manchas castanho-escuras ou negras, nos outros o colorido geral parece ser mais escuro que nos exemplares descritos por Aczél. Na lâmina mesofacial, as manchas podem ser confluentes. No macho de São Paulo, os fêmures anteriores são castanho-escuros nos dois terços basais, os médios tềm um anel pré-apical da mesma cor e os posteriores são muito escuros nos quartos basal e pré-apical, um pouco mais claros entre essas áreas, mas não tão claros aí quanto no quarto distal.

O material aqui incluído apresenta variação considerável e não concorda integralmente com a descrição de Aczél. Contudo, parece-me não ser seguro descrever uma ou mais novas espécies sem estudar cuidadosamente os tipos.

Material. BRASIL: Rio de Janeiro: Itatiaia, 700 m, 1 o. São Paulo: Barueri, 1 o; Itu, Fazenda Pau d'Alho, 2 o; São Paulo, 1 o.

\section{Leptopyngota sahlbergiana Frey}

Sob esta designação, forneço alguns comentários sobre alguns espécimes de identificação duvidosa, mas que têm evidente afinidade com o padrão descritivo geral referido na literatura pelo nome acima. São exemplares que caem nas seguintes medidas: comprimento do corpo, 9-12 mm (sem oviscapo); comprimento oviscapo, 3-4 mm; comprimento da asa, 12-15 mm; largura da asa, 3,5-5 $\mathrm{mm}$.

Não tendo acesso à descrição original de sahlbergiana, baseio-me no breve resumo preparo por Aczél. Um dos exemplares que examinei, o da Cantareira, foi identificado por Aczél como sahlbergiana. Segundo ele, a descrição se refere a dois processos apicais divergentes no ovipositor. Acredito que há ai um engano. Um pouco antes do ápice do ovipositor, há um processo ventral mais ou menos digitiforme. Com a deformação que sofre costumeiraménte o ovipositor em exemplares de coleção, com as drásticas alteraçðes de forma e a dificuldade de interpretação que daí decorrem, penso que possivelmente o autor da espécie se equivocou. Entretanto, não posso afirmá-lo. A presença do processo mencionado caracteriza sahlbergiana, como aqui a interpreto, e as três espécies que a seguir descrevo como celeriuscula, accolens e apposita.

Material. BRASIL. São Paulo: Barueri, 1 ๆ, 5. XII.1958, K. Lenko col.; Eldorado, 1 q, XII.1932, M. A. col.; Juquiá, Fazenda Poço Grande, 1 \&, 1-5.X.1940. C.D.Z. col.; Presidente Epitácio, Pto. Albano, Rio Paraná, 1 \&, X.1954, J. Lane col.; Salesópolis, Est. Biol. Boracéia, 850 m, 1 §, 22.XI.1959, L. Travassos Fo.; Salesópolis, Est. Biol. Boracéia, 1 १, 11.XI.1960, K. Lenko col.; Serra da Cantareira, Cuca, 1, , 5-9.XII.1940, Guimarães \& Travassos Fo. col. 


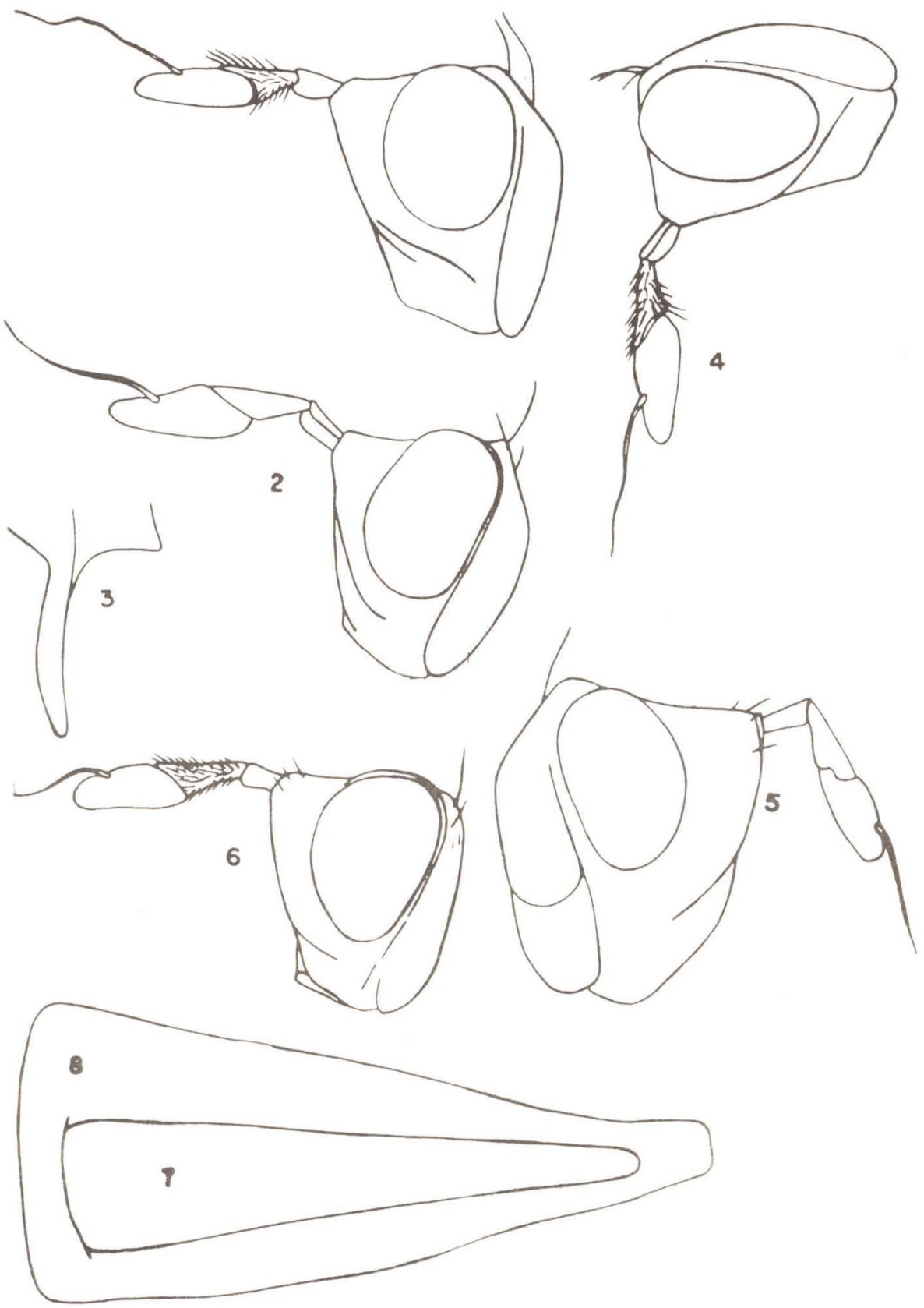

Figuras 1 a 8

Cabeça, vista lateral. 1. apposita. 2. celeriuscula. 4. accolens. 5.quaerens. 6. ensifera. A pêndice abdominal. 3. celeriuscula. Oviscapo, vista superior. 7. ensifera. 8. liae. 
Comprimento corpo (sem ovisc.), $8 \mathrm{~mm}$; compr. ovisc., $3 \mathrm{~mm}$; comp. asa, $10 \mathrm{~mm}$; larg. asa, $3 \mathrm{~mm}$.

Parte posterior da cabeça castanha, tostada. Fronte quase toda castanho-escura, quase negra. Essa cor desce pelos lados das antenas até flanquear o começo da placa mesofacial; aí é ligeiramente avermelhada. O limite posterior dessa cor tem forma de $\mathrm{M}$, atrás do qual a cor é igual à da parte posterior da cabeça. Como em accolens, há um longo triângulo central de polinosidade cinzenta. Face castanho-claro. A mancha infra-ocular é escura, mas não muito intensa, difusa, sem limites definidos e não atinge o canto da gena. Placa mesofacial com três manchas nítidas: a superior, ao pé das antenas, pequena, alongada; as inferiores, encostadas nas margens e colocadas na elevação da placa, pouco acima da margem oral. Palpos castanho-laranja, achatados. Primeiro e segundo (menos o processo dorsal) segmentos da antena castanho-escuros. Processo dorsal do pedicelo avermelhado. Pós-pedicelo também castanho-avermelhado na base, tornando-se escuro para o ápice. Arista logo adiante do meio do pós-pedicelo.. Fronte, de cima, aproximadamente tão larga quanto um olho. Cabeça pouco mais alta que longa. Olhos com dois terços da altura da cabeça. 1 vti, 1 vte, pvt paralelas.

Tórax castanho, tostado, razoavelmente escuro, sem colorido diferencial. Halteres castanho-claros, opacos. Cerdas: 1 stpl, 1 ptpl, 1 mspl, 2 ntpl, 1 ssa, 2 pa, 1 sc. As outras cercas torácicas são difíceis de distinguir, pois há grande número de pequenas cerdas no mesonoto, com algumas de maior tamanho. Pernas castanhas, as anteriores mais claras, as médias e posteriores mais escuras, especialmente nas tíbias. Estrangulamento das tíbias posteriores bastante acentuado. Asas com escurecimento ântero-apical, mas sem mancha nítida. Além disso, escurecimento muito acentuado do estigma e partes delimitantes da subcosta e primeira radial.

Pré-abdome castanho-escuro, oviscapo mais claro que ele. Sintergito três vezes mais longo que o $3^{0}$. tergito. Oviscapo muito mais curto que o pré-abdome e com processo ventral antes do ápice. Esse processo, de perfil é digitiforme, estreitando-se para o ápice de trás é triangular; é aproximadamente igual ao segmento final do oviscapo.

Esta espécie é muito semelhante a accolens, de que difere pelo colorido geral mais escuro, mancha da fronte mais escura, manchas mesofaciais, forma da cabeça, ausência de faixas no mesonoto, quetotaxia, cor do estigma, forma do processo ventral do oviscapo.

Ver comentários em sahlbergiana.

Material. BRASIL. Santa Catarina: Pinhal, 1 (holótipo), XII.1955, A. Maller.

Leptopyrgota celeriuscula, sp.n.

(Fig. 2, 3)

Compr. corpo (s/ovisc.), $7 \mathrm{~mm}$; compr. ovisc., $3 \mathrm{~mm}$; compr. asa, $10 \mathrm{~mm}$; larg. asa, $2,5 \mathrm{~mm}$.

Parte posterior da cabeça quase toda castanho-escura, mas clara, amarelada no quarto inferior e numa mancha arredondada logo atrás do vértice. Fronte castanha muito escura, quase negra, desde o vértice até atrás e ao lado das antenas; aí toma cor castanho-avermelhada-escura. A fronte só nðo tem a cor mencionada em duas estreitíssimas faixas que flanqueiam os olhos; ai é castanha, continuando a cor da face. Face castanha, com mancha infra-ocular escura seguida de curto escurecimento. Placa mesofacial larga, de lados quase paralelos, com trés manchas pequenas: uma, redonda, ao pé das antenas e duas distais, alongadas, entre o meio e os lados da face, logo acima da margem oral. Pal- 
pos amarelos. Escapo castanhoescuro; pedicelo também escuro, mas menos que o escapo; processo dorsal do pedicelo ainda mais claro; pós-pedicelo castanho, muito claro na base e escurecendo em direção ao ápice. Arista branca, com base castanha, mais longa que pedicelo e pós-pedicelo somados, pouco depois da metade do último. Fronte bastante côncava, nitidamente mais estreita que a largura de um olho, vista de cima. Olhos elevados em relação ao nível da fronte e com dois terços da altura da cabeça. 1 vti, 1 vte; 1 pvt longas e muito divergentes.

Tórax castanho muito escuro, mais escuro no mesonoto, mas claro na parte ventral e posterior das esternopleuras. As faixas mesonotais comumente encontradas no gênero săo aqui formadas de polinosidade cinzenta; as centrais são muito estreitas. Halteres amarelos. Cerdas: $1 \mathrm{stpl}, 1$ mspl, 1 ptpl, 2 ntpl, $1 \mathrm{sa}, 2$ pa, 1 dc, 1 sc. Essas cerdas são bastante longas e fortes. Pilosidade do tórax, inclusive pleuras, consideravelmente longa, embora esparsa. Pernas castanhas, tíbias e tarsos anteriores e médios e tíbias posteriores um pouco mais escuros. Asas estreitas e longas. A curvatura $\mathrm{R} 2+3$ é muito acentuada. Năo há mancha alar bem formada, mas sim um escurecimento ântero-apical cujo limite interior é uma diagonal que corre do canto ântero-distal da célula discoidal até a costa, a uns dois terços da distância entre o ápice e o nível da transversal posterior.

Pré-abdome castanho, mas terço basal do sintergito muito escuro, em nítido contraste com o restante. Oviscapo castanho, diminuindo de intensidade para o fim; muito largo na base, diminuindo para o ápice; esta deformado no holótipo, mas dá a impressāo de ser consideravelmente achatado; é menor que o pré-abdome. Na altura de uns três quartos da base, há um longo processo ventral, duas vezes mais longo que o segmento final do oviscapo; visto de lado, esse processo é digitiforme e consideravelmente estreitado na ponta, visto de trás é umas trés vezes mais largo na base que na porção média e diminui muito de largura da base ao ápice. Sintergito três vezes mais longo que o 3 . tergito.

Ver comentários em sahlbergiana.

Material. BRASIL. São Paulo: Barueri, 1 9(holótipo), XII.1966, K. Lenko.

\section{Leptopyrgota accolens, sp.n.} 2,5 mm.

Compr. corpo (s/ovisc.), $7 \mathrm{~mm}$; compr. ovisc. $3 \mathrm{~mm}$; compr. asa, $9 \mathrm{~mm}$; larg. asa,

Parte posterior da cabeça castanha, muito clara, ligeiramente escurecida no topo da placa cerebral. Fronte inteiramente avermelhada até os lados e um pouco adiante dos antenas; essa cor é mais intensa nos lados e mais fraca logo atrás das antenas. Observando-se a fronte em diagonal, vé-se um longo triângulo central (dirigido para as antenas) de polinosidade cinzenta. Face castanha, clara. Mancha infra-ocular muito clara, embora definida, e continuada por escurecimento da mesma cor até o canto da gena. Na placa mesofacial, só há uma minúscula mancha difusa ao pé das antenas. Palpos amarelos, achatados. Primeiro segmento antenal castanho-escuro, segundo castanho, terceiro castanho-amarelado. Arista longa, logo depois do meio do pós-pedicelo. Fronte, de cima, larga, ligeiramente mais larga que um olho. Cabeça vez e meia mais alta que longa. Olhós grandes, com mais de dois terços da altura da cabeça. 1 vti; 1 pvt (divergentes).

Tórax castanho. As faixas costumeiras do mesonoto amarelas; as duas centrais pouco mais largas no bordo anterior do mesonoto, interrompidas bem antes da sutura, prosseguindo pouco depois dela e terminando, mais estreitas, antes do bordo posterior; 
as laterais, largas antes da sutura, estreitam-se depois dela e terminam praticamente no fim do nesonoto. Halteres amarelos, desbotados. Cerdas longas: $1 \mathrm{stpl}, 1 \mathrm{mspl}, 1 \mathrm{ptpl}$, $2 \mathrm{ntpl}, 1 \mathrm{sa}, 1 \mathrm{pa}, 1 \mathrm{dc}, 1 \mathrm{sc}$. Pernas castanhas. Asas longas, com incipiente escurecimento ântero-apical, mas sem mancha bem formada.

Pré-abdome e oviscapo castanhos, pouco mais escuros que o tórax. Sintergito três vezes e meia mais longo que o $3^{0}$. tergito. $\mathrm{O}$ oviscapo tem um processo ventral digitiforme (tanto em vista lateral, quanto posterior) de comprimento aproximadamente igual ao segmento final do oviscapo (ou seja, a parte posterior ao processo). Oviscapo com aproximadamente o mesmo comprimento do pré-abdome.

Ver comentários sob apposita e sahlbergiana.

Material. BRASIL São Paulo: São José dos Campos, 1 q(holótipo), XII.1934, H.S. Lopes.

\section{Leptopyrgota quaerens, sp.n.}

(Fig. 5)

Compr. corpo, $11 \mathrm{~mm}$; compr. asa, $10 \mathrm{~mm}$; larg. asa, $3 \mathrm{~mm}$.

Cabeça castanho-clara, ligeiramente mais escura na fronte. Há, ao lado e atrás das antenas, até a metade da fronte,uma mancha ligeiramente avermelhada de contorno arredondado. No topo da placa cerebral, há duas manchas castanho-escuras de contorno difuso. A mancha infraocular e as três mesofaciais são praticamente negras; a primeira é triangular, diminuta e dela até o canto da gena há um escurecimento castanho difuso. A calha formada pela união das fóveas antenais é larga e curta, tomando pouco mais que os dois terços superiores da face. Ela se eleva no limite inferior; daí há um declive uniforme até a margem oral. A mancha mesofacial superior é triangular alongada, as inferiores são menores, alongadas, e colocadas nos lados da elevação descrita acima. Primeiro segmento antenal e segundo (menos o processo dorsal) castanhos, pouco mais escuros que a cabeça. Processo dorsal do pedicelo e pós-pedicelo mais claros. Arista nitidamente depois da metade do pós-peđicelo. Fronte, de cima, bem mais larga que um olho. Cabeça pouco mais alta que longa. Genas amplas e occipío bastante inchado. Olhos pequenos, bem afastados das partes anterior e inferior da cabeça e com pouco mais da metade de seu comprimento e sua altura. Um par de pvt divergentes. A fronte leva alguns pelos esparsos atrás das antenas.

Tórax castanho muito claro, tendendo ao laranja, pouco mais escuro no mesonoto e escutelo, sem qualquer marca diferencial. Halteres amarelos. Cerdas; $1 \mathrm{mspl}$, $1 \mathrm{stpl}$, 1 ptpl, 2 ntpl, 1 sa, 1 pa, 1 dc, 1 sc. Pernas castanhas, coxas mais claras. Asas translúcidas, com escurecimento ântero-apical até uns dois terços da distância entre o ápice e o nível da transversal posterior, mas sem mancha nitidamente formada.

Abdome castanho, ligeiramente mais escuro que o mesonoto. Sintergito basal duas vezes mais longo que o 3 . tergito.

Material. BRASIL: Minas Gerais: Serra do Cipó, Jaboticatubas, $1 \delta$ (holótipo), X.1975, S.A. Vanin \& C.G. Froelich.

Leptopyrgota ensifera, sp.n.

(Figs. 6, 7)

Compr. corpo (s/ovisc.), 7,5 mm; compr. ovisc., $4 \mathrm{~mm}$; compr. asas, $9 \mathrm{~mm}$; larg. asa, $3 \mathrm{~mm}$. 

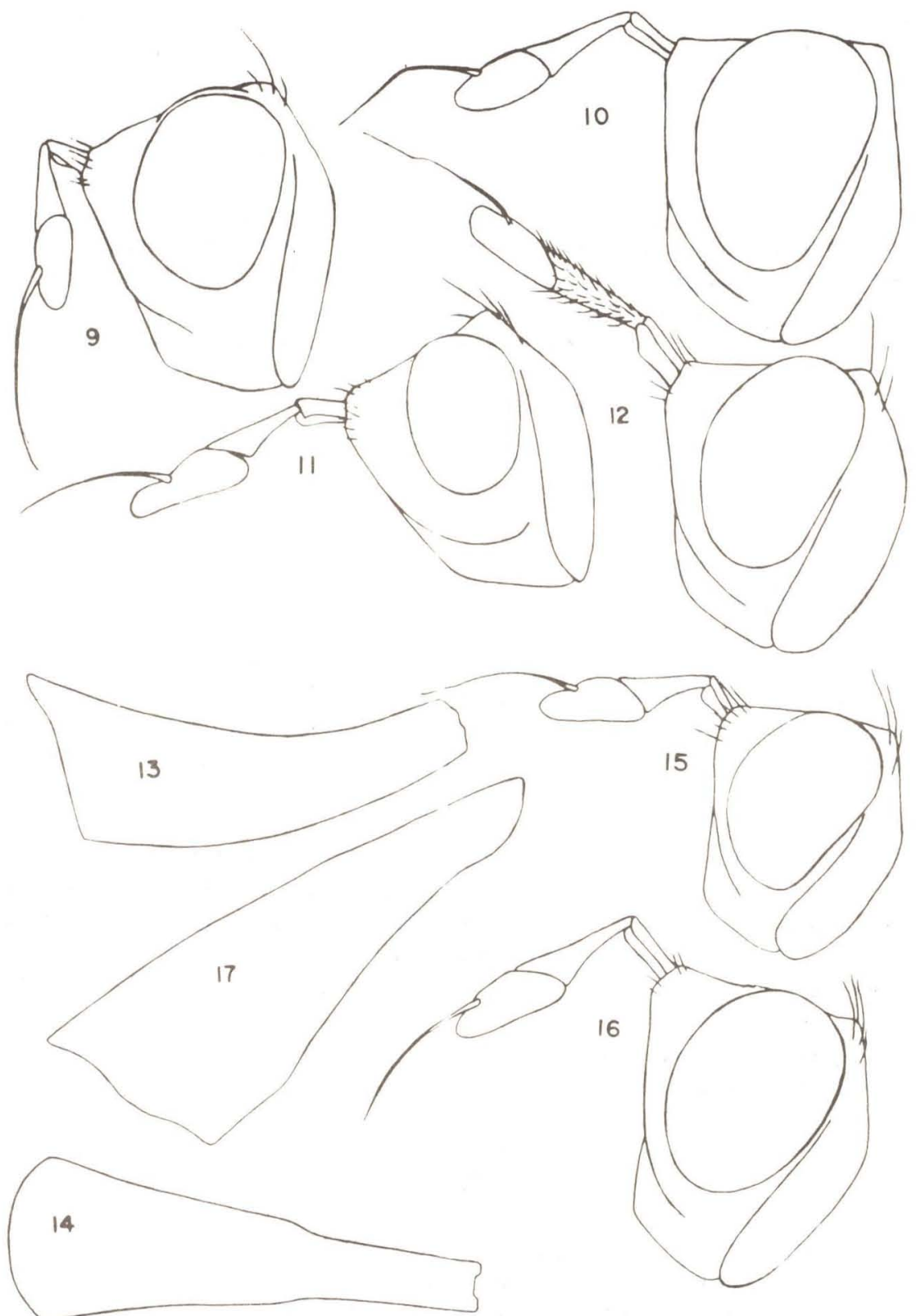

Figuras 9 a 17

Cabeça, vista lateral. 9. definienda, ठ 10 . definienda, .11 . cocta. 12. andrei. 15, marci. 16. sarae. Oviscapo. 13. andrei, lateral. 14. andrei, dorsal. 17. sarae, lateral. 
Cabeça quase uniformemente castanha, ligeiramente avermelhada na fronte. Perceptíveis, na fronte, atrás e ao lado das antenas, dois esboços de manchas mais escuras, e mais três na metade posterior; esses escurecimentos, todavia, não estão nitidamente formados e delimitados. Mancha castanho-escura infra-ocular pequena; daí até o canto da gena, escurecimento avermelhado difuso. Placa mesofacial larga, com as três manchas usuais muito nítidas: a superior, ao pé das antenas, alongada, avóide; as inferiores, laterais, triangulares, alongadas, pouco acima da margem oral. Antenas castanhas, primeiro segmento escuro. Arista relativamente curta, pouco adiante do meio do pós-pedicelo. Fronte longa e estreita, bem menor, de cima, que a largura de um olho. Cabeça, de perfil, sutriangular; occipício pouco saliente. Olhos com cerca de dois terços da altura da cabeça, um pouco elevados em relação ao plano da fronte. Concentração (pequena) de pêlos curtos no terço anterior da fronte, um pouco mais longos perto das antenas. 2 ors, 1 vti, 1 vte (muito curtas).

Tórax castanho, mais escuro nas mesopleuras e pleuras inferiores. Mesonoto também mais escuro, especialmente atrás da sutura, até o escutelo. As faixas longitudinais compreendidas entre as linhas dorso-centrais estão formadas, mas não atingem os bordos anteriores nem os posteriores do mesonoto e seu colorido não é de natureza a estabelecer contraste muito nítido com o resto do mesonoto. Mediotergito muito escuro, quase negro. Haste dos halteres castanhoescuras, capítulos claros, opacos. Cerdas: 1 mspl, 1 ptpl, 2 ntpl, 1 sa, 1 pa, 1 sc; todas longas, as sc cruzadas. Pernas castanhas (as coxas posteriores mais escuras), sem cores diferenciais. Asas largas, com mancha ântero-apical até a metade da distância entre o ápice e o nível da transversal posterior.

Abdome, inclusive oviscapo, inteiramente negro. Sintergito nitidamente peciolado, no meio com um terço da largura do 3 ? tergito e duas vezes mais longo que ele. Oviscapo mais estreito que o pré-abdome, mas bem mais longo que ele é muito característico: em vista dorsal, diminui uniformemente de largura até o ápice; em vista lateral, é bastante comprimido.

A forma do oviscapo e a cor do abdome fazem supor certa semelhança entre esta espécie e Lopadops nigerrima Enderlein. Outros caracteres, entretanto, não concordam com os diagnósticos daquele gênero. A nova espécie tem a célula anal com a forma usual no gênero e tem cerdas escutelares bem desenvolvidas. É possível que o gênero Lopadops represente um ramo mais derivado de Leptopyrgota e que os dois não sejam grupos-irmãos.

Material. BRASIL. Såo Paulo: Cajuru, Cássia dos Coqueiros, 1 @ (holótipo), II.1955, M.P. Barretto.

\section{Leptopyrgota definienda, sp.n.}

(Figs. 9, 10)

ð. Compr. corpo, 9,5 mm; compr. asa, $11 \mathrm{~mm}$; lar. asa, $3 \mathrm{~mm}$.

Cabeça amarela. Atrás das antenas e partindo de seus flancos, há uma área ligeiramente avermelhada, arredondada, que vai até quase metade da fronte. Occipício quase todo castanho-escuro, quase negro, com pequena área amarela triangular no topo da placa cerebral. Abaixo de cada olho, uma nítida mancha da mesma cor, continuada por escurecimento menos nítido que se alonga até o canto da gena. Placa mesofacial quase que inteiramente castanha muito escura, quase negra, brilhante. Essa cor cobre todos os lados da placa, inclusive a margem oral; há nela um enclave amarelo, com a seguinte forma: um pequeno triângulo, um pouco acima da margem oral, prolongado para trás atra- 
vés de uma linha estreita, contínua com ele e com outro triângulo alongado quase no meio da placa. Primeiros dois segmentos antenais castanho-escuros, o processo dorsal do pedicelo mais claro. Terceiro segmento bem mais claro, especialmente na porção basal, e opaco; leva arista longa e muito fina pouco adiante do meio. Fronte, de cima, aproximadamente tão larga quanto um olho. Olhos com cerca de dois terços da altura da cabeça. Pvt ausentes; 1 vti. Palpos achatados, cor laranja com extremidade negra.

Tórax castanho muito escuro, quase negro, brilhante, com exceção de duas manchas amarelas opacas: uma, redonda, no mesonoto, logo adiante do escutelo; outra tomando quase todo o disco e a margem posterior do escutelo. Halteres castanho-claros, com capítulo escuro, opaco. Cerdas: $1 \mathrm{mspl}, 1 \mathrm{ptl}, 1 \mathrm{ntpl}, 1 \mathrm{sa}, 2 \mathrm{pa}, 1 \mathrm{dc}, 1 \mathrm{sc}$ (cruza. das). Coxas anteriores castanho-claras, fêmures e tribias mais escuros. Pernas médias, até dois braços do primeiro artículo tarsal, castanho-avermelhadas. Pernas posteriores, até os fêmures, e mais a parte espessada das tíbias, castanho-avermelhadas. Parte basal das tíbias posteriores, até o nível do estrangulamento, castanho-claras. Tarsos anteriores e médios (a partir do terço terminal do primeiro artículo) castanhoescuros. Tarsos posteriores brancos. Asas hialinas, nervuras castanho-escuras, mas claras na raiz da asa. Mancha ântero-apical nítida, atingindo o nivel da transversal posterior. Abdome castanho, com a metade basal do sintergito muito escura. Sintergito três vezes mais longo que o 3 . tergito.

9. Compr. corpo (sem oviscapo), $9 \mathrm{~mm}$; compr. oviscapo, $4 \mathrm{~mm}$; compr. asa, 12 $\mathrm{mm}$; larg. asa, $4 \mathrm{~mm}$.

Difere do macho no seguinte: área amarela do occipício mais extensa. Enclave amarelo da placa mesofacial mais largo. Tarsos anteriores e médios castanhos, da mesma cor que as tíbias. O oviscapo está deformado, mas revela o seguinte: subcônico, na base nitidamente mais largo que o pré-abdome e da mesma cor que este último.

Material. BRASIL. Rio de Janeiro: Itatiaia, 700 m, 1 ơ(holótipo), 1.XII.1947, J.F. Zikán, 1 parátipo $\&$, mesmos dados, mas 21.XI.1929.

\section{Leptopyrgota cocta, sp.n.}

(Fig. 11)

Compr. corpo, $9 \mathrm{~mm}$; compr. asa, $9,5 \mathrm{~mm}$; larg. asa, $3 \mathrm{~mm}$.

Cabeça com colorido de fundo castanho-tostado, um pouco mais brilhante na frente dos olhos e na lâmina mesofacial. Uma grande mancha negra cobre a fronte por aproximadamente dois terços de sua extensão e tem as seguintes características: atrás, a um quarto do término da fronte, apresenta duas projeções arredondadas e uma reentrância média dirigida para as antenas; é separada dos olhos por uma estreita faixa da cor da fronte posterior; entre esses limites, cobre toda a fronte anterior, até as antenas; desce um pouco abaixo das antenas, encostadas no início da lâmina mesofacial. Abaixo de cada olho, há também uma grande mancha escura que vai da órbita até o canto da gena, daí se prolonga, larga, até a margem lateral inferior da lâmina mesofacial. Ligando o término dessa mancha com o término da mancha frontal, há um ligeiro e estreito escurecimento que bordeia os flancos da lâmina mesofacial. Essa lâmina abriga três manchas muito escuras: uma, pequena, central, ao pé das antenas e duas, umas trés vezes maiores que a primeira, alongadas, laterais, no bordo anterior da lâmina. Primeiros dois segmentos antenais castanhos, não muito escuros, o segundo quase duas vezes mais longo em cima que embaixo. $O$ terceiro é avermelhado na base, por maior extensão na face interna 
que na externa, e castanho, opaco, daí em diante. Arista longa, larga e castanho-avermelhada na base, branca depois, inserida logo adiante do meio do terceiro segmento. As pvt não se fazem presentes no holótipo, mas vêem-se seus pontos de inserção bastante para trás da margem vertical. Uma vti de cada lado; póspostas a elas, mais alguns pelos menores. Ao lado e um pouco abaixo das vti, após a linha demarcatória da placa cerebral, há uma outra cerdinha um pouco menor. Há um par de orbitais superiores fortemente convergentes, terminando na linha média da fronte. Alguns pêlos na parte anterior da fronte. Fronte ligeiramente convergente para trás e com largura nitidamente maior que a de um olho, em vista superior. Cabeça um pouco mais alta que longa. Olhos pequenos, não muito mais altos que longos, ligeiramente oblíquos atrás, com pouco mais da metade do comprimento da cabeça e metade de sua altura.

Tórax castanho-escuro, tostado, sem colorido dife rencial conspícuo. No mesonoto há um prelúdio de escurecimento nas áreas que freqüentemente levam faixas. Halteres castanhos, mais claros que o resto do tórax. Cerdas: $1 \mathrm{stpl}, 1 \mathrm{ptpl}, 2 \mathrm{ntpl}, 1 \mathrm{sa}, 1 \mathrm{dc}, 1 \mathrm{sc}$. As escutelares são fortemente cruzadas. Pernas castanhas, tostadas, avermelhadas. A extremidade das tíbias posteriores e os tarsos posteriores são mais escuros. Asas hialinas, com nervuras castanhas e um apreciável escurecimento ântero-apical até $\mathrm{M} 1+2$, mas sem mancha bem formada.

Abdome castanho, mais escuro que o tórax. Sintergito umas duas vezes e meia mais longo que o 3 . tergito.

Material. BRASIL. Santa Catarina: Pinhal, 1 o (holotipo), XII. 1955, A. Maller.

\section{Leptopyrgota andrei, sp.n.}

(Figs. 12, 13, 14)

Compr. corpo (sem oviscapo), $11 \mathrm{~mm}$; compr. oviscapo, $3 \mathrm{~mm}$; compr. asa, 12 $\mathrm{mm}$; larg. asa, 3,5 mm.

Cabeça castanho-clara atrás e castanho-avermelhada na fronte e genas; lâmina mesofacial um tanto transparente, amarelo-opaca. Fronte mais clara ao longo das margens orbitais e vertical. Essa cor desce pelo lado das antenas, acompanhando as órbitas e a lâmina mesofacial, depois vira para trás, muito estreita, separando a mancha infra-ocular de uma faixa escura adjacente à margem oral que se alonga desde a placa mesofacial até o canto da gena. Uma minúscula mancha, mal delimitada, ao pé das antenas e um escurecimento triangular ainda menos nítido na lâmina mesofacial, em cima da margem oral. Primeiros dois segmentos antenais castanho-escuros, o segundo, visto de cima, claro no ápice. Terceiro segmento amarelo, opaco, curto. Arista com aproximadamente o comprimento do pedicelo e pós-pedicelo somados, no meio do pós-pedicelo. Cerdas: 1 pvt (convergentes) e 1 vti. Fronte plana, mais larga que um olho (em vista superior), mas mais estreita que metade da largura da cabeça. Cabeça um tanto mais alta que longa, com olhos largos que ocupam quase três quartos de sua altura.

Tórax castanho muito claro, quase amarelo, com as seguintes manchas castanhas: duas faixas centrais no mesonoto do bordo anterior até três quartos de sua extensão e duas laterais, mais largas, interrompidas na sutura, que diminuem de largura e atingem o fim do mesonoto; uma pequena mancha em cada lado da margem posterior do escutelo; mancha grande em quase todo o mediotergito; uma faixa vertical na metade anterior da mesopleura; uma grande mancha na metade ventral da esternopleura. Cerdas relativamente pequenas: $1 \mathrm{stpl}, 1 \mathrm{mspl}, 1 \mathrm{ptpl}, 1 \mathrm{~h}, 1$ intpl, $1 \mathrm{sa}, 2 \mathrm{pa}, 1 \mathrm{dc}, 1 \mathrm{sc}$. Pernas longas e 


\section{Vol. 7(3), 1990}

delgadas, castanho-claras, sem qualquer escurecimento ou mancha diferencial. Halteres castanho-claros, com o capítulo ligeiramente escurecido. Asas hialinas, com mancha escura ântero-apical muito nítida, atingindo o segundo terço da distância entre o ápice e a altura da transversal posterior.

Todo o abdome castanho, tostado, mais escuro aqui e ali. O 1 ? e o 2 ? tergitos parecem separados, o 1 . é menos que uma vez e meia mais longo que o 2 ?; o 3 ? é um pouco menor que o 2 \%. Oviscapo nitidamente menor que o pré-abdome, menos largo que ele na base, cônico, com ápice truncado, curvado progressivamente para cima; visto de cima, apresenta um estreitamento no início do terço distal, daí em diante com lados paralelos.

O nome da espécie é dado em memória de meu filho André F. Bernardi.

Material. BRASIL. São Paulo: Salesópolis, Estação Biológica de Boracéia, 1 ९(holótipo), 11.XII.1960, K. Lenko.

\section{Leptopyrgota marci, sp.n.}

(Fig. 15)

§.Compr. corpo, $12 \mathrm{~mm}$; compr. asa, $12 \mathrm{~mm}$; larg. asa, $3,5 \mathrm{~mm}$.

A cabeça parece estar um tanto comprimida na placa mesofacial, o que deixa escondido o primeiro segmento das antenas. Isso não parece ter afetado apreciavelmente a forma da cabeça.

Fronte castanho-clara nos lados e no terço posterior, mais escura em direção às antenas. A cor clara está presente em toda a face, menos na mancha escura e bem formada existente abaixo de cada olho, e nos lados do occipício. Na lâmina mesofacial há uma pequena mancha ao pé das antenas e outra, longa e triangular, sobre a margem oral. A lâmina cerebral, de fundo castanho-amarelado, leva uma larga mancha trapezoidal no topo, com a base voltada para cima, além de duas manchas ovóides, longas, mais claras, verticais, colocadas abaixo da primeira. Ao lado destas, adjacentes à linha demarcatória dả lâmina, há duas amplas manchas da mesma cor aos lados do buraco occipital. "Clípeo" preto. Primeiros dois segmentos antenais castanhoescuros, o segundo muito longo, em cima uma vez e meia tão longo quanto o terceiro. Este castanho-avermelhado, mais escuro ântero-apicalmente, carregando além da metade a arista longa e branca e de base castanha. Pvt e vti rudimentares. Cabeça comprimida, duas vezes mais alta que longa. Olhos com quase dois terços da altura da cabeça, ligeiramente oblíquos atrás. Fronte, vista de cima, quadrada, com aproximadamente a largura de um olho.

Tórax com colorido de fundo castanho muito claro, amarelado, com diversas manchas negras ou castanhas muito escuras, quase negras, descritas em seguida. Uma mancha cobre quase todo o lobo umeral. Uma faixa muito larga, central, parte do bordo anterior do mesonoto, é muito nítida até quase um terço dele, depois torna-se desbotada e prolonga-se por uma faixa muito estreita, esmaecida, até depois da linha da sutura, quando se alarga novamente, terminando a um quarto do comprimento do mesonoto. Duas faixas laterais, interrompidas na sutura, correm, estreitando-se um pouco, até os lobos pós-alares. A parte pós-sutural dessas faixas está em perfeita confluência com o segmento posterior da faixa central; além disso, prolonga-se lateralmente por trás do lobo notopleural. Outra mancha cobre todo o escutelo, em cima, descendo para os lados da margem posterior; o tegumento central da margem tem o colorido de fundo. O mesmo acontece com o pósescutelo. Uma enorme mancha cobre praticamente todo o mediotergito. Uma faixa corre, pelo meio, de cima a baixo do látero-tergito superior, prolongando-se 
para o lado, até a base do inferior, em cima do espiráculo. Uma mancha cobre toda a propleura. Uma faixa vertical muito larga cobre quase inteiramente os dois terços anteriores 'da mesopleura, emitindo um largo prolongamento para a frente, até imediatamente atrás do espiráculo. A mesma faixa contínua, bem mais larga, por todo o meio da estemopleura. Há ainda uma faixa vertical na metade anterior da pteropleura e uma mancha na frenre e ao lado da coxa posterior. Halteres castanho-claros, ligeiramente mais escuros no capítulo. Cerdas: $1 \mathrm{mspl}, 1 \mathrm{ptpl}, 1 \mathrm{ntpl}, 2 \mathrm{pa}, 1 \mathrm{dc}, 1 \mathrm{sc}$. Pernas castanho-claras, mais tostadas que o colorido de fundo do tórax. Os pêlos são avermelhados. Os artículos finais dos tarsos anteriores e médios são um pouco mais escuros que o resto das pernas. (No holotipo faltam os tarsos posteriores). Os fêmures anteriores são castanhoescuros no meio, em ahel, com a mesma cor prolongando-se para a base na face interna. Os médios săo castanho-escuros na base e além do meio, em anel. Os posteriores têm essa cor escura em quase toda a extensão, menos num pequeno segmento apical e metade da face externa. Tíbias médias com ligeiro escurecimento logo após o meio. Asas hialinas, com mancha ântero-apical que atinge três quartos da distância entre o ápice e a altura da transversal posterior.

$\mathrm{O}$ sintergito é amarelado na base, em dois triângulos laterais no meio e na margem posterior; de resto, é negro. O $3^{\circ}$. tergito é orlado de castanho-amarelado nas margens laterais e posterior, com larga faixa dessa cor na margem basal; de resto, a metade posterior é negra, com a mesma cor estendendo-se em triângulo para dentro da metade anterior. O $4^{\mathrm{O}}$. tergito é quase todo negro, com as quatro margens, estreitas, castanho-amareladas. $\mathrm{O}$ último tergito não tem tons claros. Os esternitos são castanhos, a base do primeiro é negra.

१. Compr. corpo (sem oviscapo), $7 \mathrm{~mm}$; compr. oviscapo, 2,5 mm; compr. asa, $9 \mathrm{~mm}$; larg. asa, $3 \mathrm{~mm}$.

Fronte amarelo-bronzeada; face amarela. A parte de trás da cabeça, em cima, da mesma cor da fronte, tornando-se progressivamente clara para baixo, onde é da cor da face. Lâmina mesofacial clara, com duas manchas grandes castanho-escuras: uma, ao pé das antenas, com quase um terço do comprimento da lâmina, em cima tão larga quanto ela; outra embaixo, triangular, projetando-se até o meio da lâmina. Há uma pequena mancha, um pouco mais clara que as descritas, abaixo de cada olho. Primeiros dois segmentos antenais castanhos, muito escuros; terceiro castanho-claro. Arista praticamente tão longa quanto $2^{\circ}$. e $3^{\circ}$. segmentos somados e inserida pouco além da metade do $3^{\circ}$ Cabeça um pouco mais alta que longa. Olhos grandes, com mais de três quartos da altura da cabeça, ocupando quase todo seu comprimento e bastante oblíquos atrás. Fronte nitidamente mais larga na metade anterior que na posterior, aí menos larga que um olho. Pvt curtas, convergentes; vti com quase o dobro do comprimento daquelas; um pouco abaixo e ao lado das vti, há vte tão longas quanto as pvt. Uma série de pequenos pélos na margem anterior da fronte.

Tórax de colorido bronzeado uniforme, um pouco mais nítido e brilhante que a fronte. Em nítido contraste com a coloração clara do mesonoto, vê-se pequenas cerdas pretas com disposição mais ou menos regular; algumas inserem-se no lobo umeral. No meio do mesonoto, duas pequenas fileiras de acrosticais. Duas fileiras de dorsocentrais correm ao longo de todo o mesonoto, as posteriores são umas duas vezes maiores que as anteriores. Ao lado das dorso-centrais, há poucas dessas cerdinhas antes da sutura e número bem maior depois da sutura. Outras cerdas: $1 \mathrm{mspl} \mathrm{e} 1 \mathrm{ptpl}$ longas, 1 stpl mais curtas, 1 ntpl, 8 a e pa difíceis de definir, mas há pelo menos uma longa de cada tipo; 


\section{Vol. $7(3), 1990$}

$1 \mathrm{sc} \mathrm{longa.} \mathrm{Halteres} \mathrm{inteiramente} \mathrm{amarelo-claros,} \mathrm{opacos.} \mathrm{Coxas} \mathrm{e} \mathrm{trocânteres} \mathrm{com} \mathrm{a} \mathrm{mes-}$ ma cor do tórax, os anteriores mais claros. Fêmures anteriores, tíbias médias e todos os tarsos cläos. Fêmures médios castanhos, progressivamente mais escuros, até quatro quintos da extensăo, depois muito claros; a parte mais escura não é tão intensa quanto nos fêmures posteriores. Estes castanhos bem escuros, mais claros no ápice. Tíbias posteriores também castanhas, mais claras que os fêmures correspondentes, com estrangulamento pronunciado no fim do terço proximal, depois umas duas vezes mais espessa que na base. Pilosidade das pernas negra. Asas hialinas, com mancha ântero-apical nítida atingindo pouco mais da metade da distância entre $o$ ápice e a altura da transversal posterior. Abaixo do estigma há um ligeiro escurecimento transversal até a discoidal.

Pré-abdome e oviscapo castanho-escuros, queimados, com pêlos negros. Sintergito pouco mais de duas vezes mais longo que o $3^{\circ}$. tergito.

A julgar pela descrição e as figuras de $L$. pulchra divulgadas por Aczél (1956), aquela espécie e a que vem de ser descrita são bastante parecidas. $O$ oviscapo do holótipo de marci está um pouco deformado, como sói acontecer, mas parece-se com o de pulchra. A nova espécie difere de pulchra no seguinte: o pós-pedicelo e a arista são consideravelmente mais longos; há uma grande mancha triangular na parte inferior da placa mesofacial; parece nāo ter as cerdas orbitais descritas por Aczél; cores diferenciais nas pernas, ao contrário do colorido uniforme de pulchra; pêlos das pernas negros, e não amarelo-dourado; halteres inteiramente amarelo-claros; uma só notopleural.

Esta espécie é dedicada a meu filho Marcos S.F. Bernardi.

Material. BRASIL. Sððo Paulo: Salesópolis, E.B. Boracéia, 1 ơ (holótipo), 15.XII. 1947, E.X. Rabello; 1 9 (parátipo), 21-25.X.1963, J.H. Guimarães.

\section{Leptopyrgota sarae, sp.n.}

(Figs. 16, 17)

Compr. corpo (sem oviscapo), $10 \mathrm{~mm}$; compr. oviscapo, $4 \mathrm{~mm}$; compr. asa, 12 $\mathrm{mm}$; larg. asa, $4 \mathrm{~mm}$.

Cabeça, em toda a parte posterior e fronte, num triângulo que vai da margem vertical até a metade, castanho-clara, opaca. De trás e dos lados das antenas parte uma mancha castanho-avermelhada, mais clara logo atrás das antenas, dirigindo-se para trás e diminuindo de largura, terminando arredondada, larga, no fim do triângulo descrito acima. Essa mancha é brilhante. $\mathrm{O}$ resto da fronte é também castanho-claro, mas brilhante. Esse matiz desce até um pouco além do começo da placa mesofacial, tornando-se ligeiramente avermelhado-claro até a frente da face. Mancha escura infra-ocular presente. $\mathrm{Na}$ frente dela, até o canto da gena, um escurecimento castanho-avermelhado. A lâmina mesofacial leva uma pequena mancha subtriangular escura ao pé das antenas e duas outras, minúsculas, alongadas, pouco evidentes, um pouco acima da margem oral. Primeiros dois segmentos antenais castanho-escuros. O segundo, em cima, duas vezes mais longo que $o$ primeiro; seu processo dorsal, castanho-avermelhado, tem quase metade do comprimento do pós-pedicelo. Este é mais curto que o pedicelo, é castanho-amarelo na base e torna-se mais escuro em direção ao ápice. Arista branca, com base larga e castanho-escuro, mais comprida que pedicelo e pós-pedicelo somadas e inserida mais ou menos no meio do pós-pedicelo. Fronte, vista de cima, mais estreita que a largura de um olho. Cabeça um pouco mais alta que longa. Olhos grandes, oblíquos atrás, com mais de dois terços da altura da cabeça. Cerdas: pvt curtas, paralelas; duas vti de cada lado, uma posposta à outra, mais longas que as pvt. 
Tórax castanho, claro. As faixas castanho-escuras do mesonoto, comuns no gênero, estão presentes, embora ligeiramente apagadas: uma faixa, central, cortada longitudinalmente por uma linha mais clara, corre até pouco mais de dois terços do mesonoto; as duas faixas laterais vão até o lobo pós-alar. O escutelo leva, de cada lado, uma mancha castanho-escura. Halteres castanho-claros, um capítulo escuro. Cerdas: 1 stpl, 1 mspl, 1 ptpl, 1 ntpl, 1 sa, 2 pa, 1 dc, 1 sc. Pernas longas, castanho-claras, mais amareladas que o tórax, sem colorido diferencial e sem espessamento apreciável nas trbias posteriors. Asas hialinas, com nervuras castanho-claras com mancha ântero-apical que atinge três quartos da distância entre o ápice e a altura da transversal posterior.

Abdome castanho-scuro, especialmente no fim do sintergito e nos tergitos distais. Sintergito quase três vezes mais longo que o 3 . tergito. Oviscapo nitidamente mais curto que o pré-abdome, cônico, muito largo na base, diminuindo muito de diâmetro em direção ao ápice, que é truncado; castanho muito escuro, quase negro, na base, e castanho-claro no ápice.

A descrição acima refere-se ao holótipo. O parátipo difere em: 1 vti; as duas manchas escuras dianteiras da placa mesofacial são mais largas e mais nítidas; faixas do mesonoto não formadas; manchas do escutelo também; $1 \mathrm{~h}$; as sc não são visíveis.

Esta espécie é dedicada a minha filha Sara. F. Bernardi.

Material. BRASIL. Rio de Janeiro: Itatiaia, 700 m, 1 \% (holótipo), 23.I.1944, J.F.

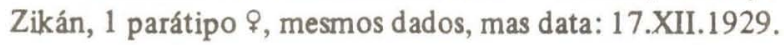

\section{Leptopyrgota juniae, sp.n.}

(Fig. 18)

Compr. corpo, $11 \mathrm{~mm}$; compr. asa, 11,5 mm; larg. asa, $4 \mathrm{~mm}$.

Cabeça castanho-avermelhada, com essa cor mais intensā na fronte, mais nítida em direção ds antenas. Um escurecimento no topo da placa cerebral, difuso. Parte inferior do occiṕ́cio e face, à frente dos olhos, castanho-amareladas. Mancha infra-ocular castanho-escura, mas com limites mal definidos, seguida imediatamente de outra, castanho-avermelhada, muito intensa, que corrẹ do canto da gena até a lâmina mesofacial $\mathrm{e}$ contínua, mais clara, por cima da margem lateral da placa. Nos cantos anteriores da fronte, há duas manchas largas que descem um pouco para o lado das antenas, adjacentes ao início da placa mesofacial. São da cor das manchas infra-oculares, mudando gradativamente para o avermelhado em cima, mas fazem contraste mais nítido com a área que lhes é adjacente embaixo, amarelada. As manchas da placa mesofacial são as seguintes: uma, ao pé das antenas, central, muito estreita, quase linear; duas, redondas, intensas, pequenas, laterais, embaixo; passando por entre essas duas, confluente com elas, uma mancha triangular mais clara se estende da margem oral até cerca de um terço do comprimento da lâmina. Primeiro dos segmentos antenais castanho-escuros, o segundo avermelhado no ápice, o terceiro avermelhado na base, tomando-se castanho-opaco em direção ao ápice. A arista, esbranquiçada e com base castanho-escura, insere-se no meio da face superior do pós-pedicelo. Há um par de vti não muito grandes; não se vêem pvt, mas pontos de inserção dessas cerdas parecem estar presentes. Cabeça um pouco mais alta que longa. Olhos largos, consideravelmente atrás e com menos de dois terços da altura da cabeça. Fronte, em vista superior, bem mais larga que um olho.

Tórax castanho-avermelhado-escuro. Halteres da mesma cor. Cerdas: 1 stpl, 1 mspl, 1 ptpl, 2 ntpl, 1 sa, 2 pa, 1 dc, 2 sc. Coxas, trocânteres e fêmures anteriores e mé- 
dios castanhos. Tíbias anteriores e médias e fêmures posteriores avermelhados. Quatro quintos das tíbias posteriores avermelhados, ainda mais intensos. Ápice đas tíbias posteriores e tarsos ainda mais escuros. A cor da pilosidade das pernas acompanha aproximadamente as cores descritas acima. 0 espessamento das tíbias posteriores, após o estrangulamento na altura do primeiro terço, é considerável. Asas hialinas, com nervuras castanhas. 0 escurecimento ântero-apical não chega a ser uma mancha bem formada, como é comum no gênero, mas é bastante apreciável e atinge $\mathrm{M} 1+2$.

Abdome inteiramente negro. Sintergito mais de duas vezes mais longo que o 3 ? tergito.

Esta espécie é dedicada a minha esposa, Junia F. Bernardi.

Material. BRASIL Rio de Janeiro: Itatiaia, 700 m, 1 o (holótipo), 22.I.1933, J.F. Zikán.

\section{Leptopyrgota liae, sp. n.}

(Figs. 8, 19)

Compr. corpo (sem oviscapo), $8 \mathrm{~mm}$; compr. oviscapo, $5 \mathrm{~mm}$; compr. asa, $10,5 \mathrm{~mm}$; larg. asas, $3,5 \mathrm{~mm}$.

Cabeça amarela atrás e na face, ligeiramente avermelhada na fronte, nos dois terços próximos, às antenas. A placa cerebral, no topo, leva uma larga faixa transversal castanha que não atinge os lados da placa. Abaixo de cada olho, uma nítida mancha subtriangular, seguida por um escurecimento menos intenso e opaco, mal formado. Duas largas faixas castanho-escuras, quase negras, brilhantes, correm longitudinalmente de alto a baixo da placa mesofacial, desde as antenas até os ângulos inferiores externos da placa. As faixas só tocam nos lados da placa no terço inferior, estando deles separadas nos dois terços superiores por estreitas amareladas. As duas faixas escuras também não se tocam no meio, estando aí separadas por uma longa cunha mediana amarela, larga na base e quase imperceptível no ápice. Primeiros dois artículos antenais castanhos, o terceiro avermelhado, curto, com arista longa, branca e muito fina, inserida logo após o meio. Palpos eretos, subcilíndricos, amarelos. Um par de pvt pequenas e cruzadas, um de vt duas vezes mais longas e um de vte. Alguns pêlos muito pequenos dispersos na metade anterior da fronte, outros, maiores, circundando as antenas.

Tórax castanho-avermelhado, claro, com polinosidade cinzenta, mais concentrada em cima. Halteres castanho-amarelos, claros, na haste e avermelhados no capítulo. Cerdas: $1 \mathrm{mspl}, 1 \mathrm{ptpl}, 2$ ntpl, 1 sa, 1 pa, $2 \mathrm{sc}$ (cruzadas). Pernas castanhas, não avermelhadas como o tórax, longas e delgadas. Tarsos posteriores brancos (inclusive os pêlos). Asas hialinas; mal se distingue um prelúdio de escurecimento ântero-apical.

Pré-abdome castanho-avermelhado, mais escuro e vivo que o tórax, o oviscapo mais ainda. Este último tem aspecto de âmbar escuro, na base é mais largo que o último tergito, é fortemente achatado, sua largura diminui progressivamente da base para o ápice (truncado) e é pelo menos tão longo quanto o pré-abdome. Sintergito três vezes mais longo que $03^{\circ}$. tergito.

Esta espécie assemelha-se a albitarsis, mas difere no seguinte: pós-pedicelo mais curto; duas faixas longitudinais escuras na lâmina mesofacial; ausência de mancha ântero-apical na asa; duas notopleurais.

Esta espécie é dedicada a minha filha Lia F. Bernardi.

Material. BRASIL. Santa Catarina: Nova Teutônia, $27^{\circ} 11^{\prime} \mathrm{S}, 52^{\circ} 33^{\prime} \mathrm{L}, 300$ 500 m, 1 q (holótipo), IX.1971, Fritz Plaumann. 
Revta bras. Zool.

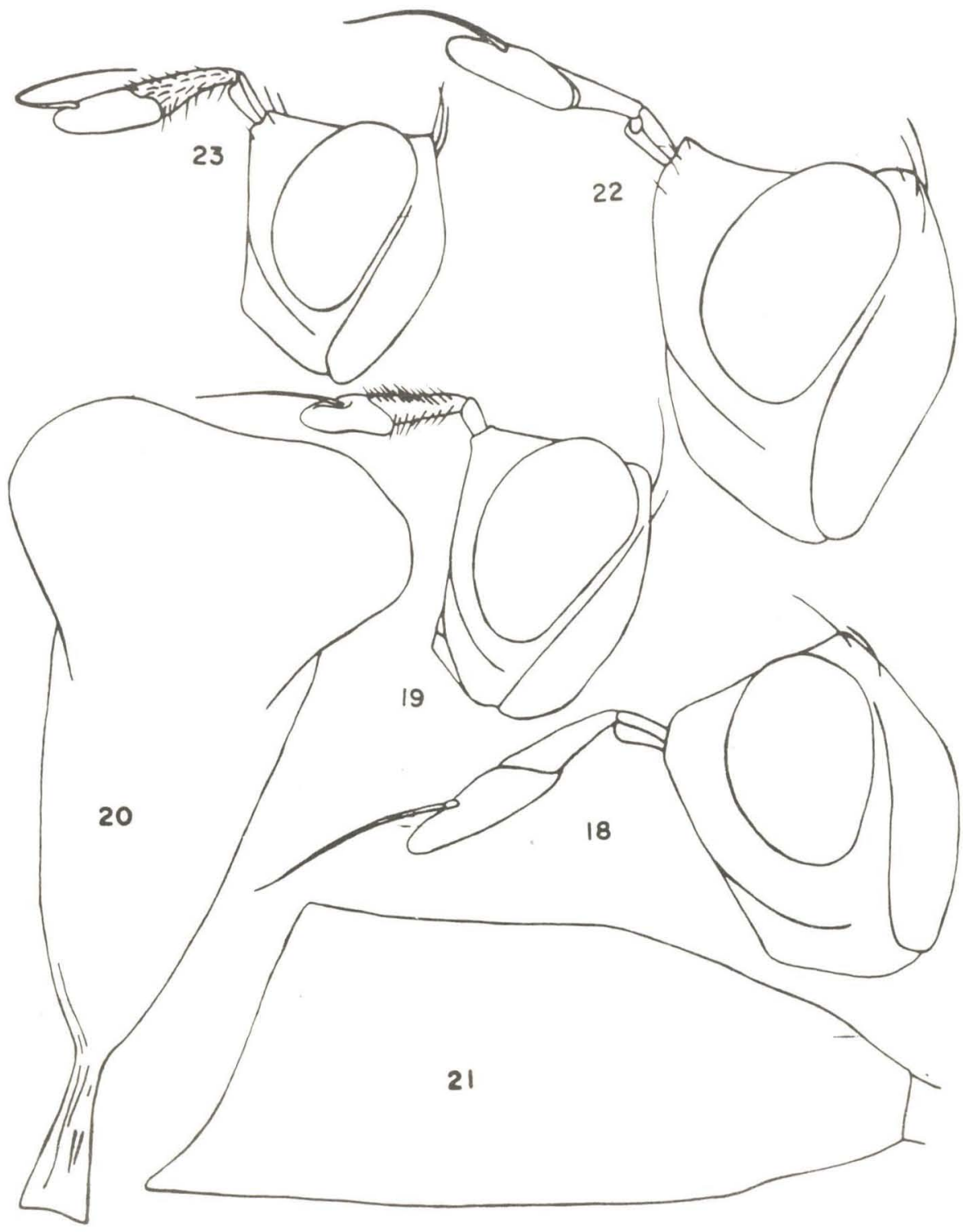

Figuras 18 a 23

Cabeça, vista lateral. 18. juniae. 19. liae. 22. isabelae. 23. gracilenta. Oviscapo, isabelae. 20. superior. 21 lateral. 
(Figs. 20, 21, 22)

Compr. corpo (sem oviscapo), $11 \mathrm{~mm}$; compr. oviscapo, $5 \mathrm{~mm}$; compr. asa, $12 \mathrm{~mm}$; larg. asa, $4 \mathrm{~mm}$.

Cabeça castanha, tostada, ligeiramente avermelhada na fronte e um pouco mais escura atrás das antenas. Mancha escura infra-ocular pequena, duas vezes mais longa que larga, mas sem atingir a metade da distância entre a órbita e o canto da gena. Na lâmina mesofacial, há uma mancha redonda grande ao pé das antenas e outra muito pequena, central, triangular, na margem oral. Antenas castanho-clarās, um pouco escurecidas no terço distal do pós-pedicelo. Arista longa, branca, com aprecíavel setor basal largo e castanho-claro. Cabeça um pouco mais alta e larga que longa. Fronte larga, quase tanto quanto metade da largura da cabeça e nitidamente mais larga, em vista superior, que a largura de um olho. Olhos com dois terços da altura da cabeça, bastante oblíquos atrás. Pvt e vti curtas.

Tórax também castanho-tostado, sem coloração diferencial apreciável. Cerdas curtas: $1 \mathrm{mspl}, 1 \mathrm{ptpl}, 1 \mathrm{stpl}, 1 \mathrm{~h}, 1 \mathrm{ntpl}, 2 \mathrm{sa}, 2 \mathrm{pa}, 1 \mathrm{dc}, 1 \mathrm{sc}$. Pemas castanho-claras, sem colorido diferencial apreciável. Haste dos halteres castanho-amareladas, capítulo escuro. Asas hialinas, com matizes opacos muito tênues ao longo do meio das células e no setor ântero-apical. A nervura M1+2, após deixar a célula discoidal, projeta-se em direção normal, mas não atinge a margem da asa, interrompendo-se a pouco mais de três quartos do trajeto. Essa interrupção é abrupta e desse ponto até a margem da asa não há qualquer vestígio ou indicação de veia.

Abdome castanhoescuro, com matizes negros no fim do sintergito e nos outros tergitos. Sintergito mais de duas vezes mais longo que o $3^{\circ}$ tergito. Oviscapo com mais ou menos o tamanho do pré-abdome, muito largo e alto da base, cônico, reto, fortemente comprimido no sexto terminal. É castanho, brilhante, mais escuro na base que no ápice.

Esta espécie é dedicada a minha filha Isabel F. Bernardi.

Material. BRASIL. São Paulo: Ribeirão Preto, Rio Tamanduá, 1 q (holótipo), X.1953, M.P. Barretto.

\section{Leptopyrgota gracilenta, sp.n.}

(Fig. 23)

Compr. corpo (sem oviscapo), $7 \mathrm{~mm}$; compr. oviscapo, 3,5 mm; compr. asa, $9,5 \mathrm{~mm}$; larg. asa, $3 \mathrm{~mm}$.

Cabeça de cor uniforme, castanho-clara, com as seguintes marcas diferenciais castanho-escuras, a primeira mencionada meio opaca, as outras nítidas: uma mancha transversai, duas vezes mais longa que larga, no topo da placa cerebral, mas sem atingir os bordos laterais da placa. Uma mancha encostada na margem inferior dos olhos, acompanhada, embaixo, por um escurecimento menos intenso, que não chega a atingir o canto da gena; três minúsculas manchas na placa mesofacial, uma, redonda, ao pé das antenas, e duas, oblongas, em cima da margem oral, entre os lados e o meio da placa. Primeiros dois segmentos antenais castanho-escuros, o terceiro castanho-claro, embotado. Arista longa, branca, com base castanho-escura, inserida no início do terço distal do tra- 
jeto superior do pós-pedicelo. Cabeça um pouco mais alta e mais larga que longa. Fronte duas vezes mais longa que larga, mais estreita que metade da cabeça e aproximadamente tão larga quanito um olho, em vista superior. Olhos com pelo menos dois terços da altura da cabeça, um pouco oblíquos atrás. Cerdas: pvt pequenas, cruzadas; 2 vti, mais longas que as pvt, as duas do mesmo lado colocadas uma atrás da outra.

Tórax castanho-claro, um tanto mais tostado que a cabeça. No mesonoto há esboços de faixas longitudinais, sendo que as dorso-centrais não atingem o meio do mesonoto. Essas marcas não são nítidas; há apenas matizes castanho-escuros contrastando cum o resto do colorido. Cerdas: 1 stpl, $1 \mathrm{ntpl}, 1 \mathrm{ptpl}, 1 \mathrm{sa}, 2 \mathrm{pa}, 1 \mathrm{dc}, 1 \mathrm{sc}$. As escutelares săo bem mais longas que as outras. Pernas castanho-claras, sem qualquer coloração diferencial conspícuo, a não ser um incipiente escurecimento no meio dos fềmures posteriores. As pernas são muito longas e delgadas, particularmente as médias e posteriores; os tarsos acompanham esse alongamento. Fêmures posteriores bem mais longos que o pré-abdome. Halteres com haste castanho-amarelada e capítulo castanho-escuro. Asas hialinas, com incipiente embotamento ântero-apical.

Pré-abdome castanho-scuro, nitidamente mais escuro que o tórax. Oviscapo longo, aproximadamente tanto quanto o pré-abdome, mais largo na base que o último tergito, depois diminuindo gradualmente, no terço distal com marcas quase paralelas, com menos de um terço da largura da base. O terço apical, em vista superior ou lateral, é reto. O oviscapo é castanho-claro, um pouco mais escuro na base. Sintergito duas vezes e meia mais longo que o 3 . tergito.

Material. BRASIL São Paulo: São Paulo (Sto. Amaro), 1 ? (holótipo), XII.1954, J. Lane.

\section{Leptopyngota flavipes, sp.n.}

(Fig. 24)

Compr. corpo, $11 \mathrm{~mm}$; compr. asa, $12 \mathrm{~mm}$; larg. asa, $4 \mathrm{~mm}$.

Espécie semelhante a lenkoi.

Tórax e pernas, até os fêmures, de colorido avermelhado muito intenso, mais vivo que em lenkoi. Fronte, face e genas castanhas, brilhantes, com as seguintes marcas: uma pequena, arredondada, ao pé das antenas; duas, alongadas, acima da margem oral; uma, grande, desde a margem inferior de cada olho, ocupando todo o canto da gena e seguindo pela margem oral até a placa mesofacial. Fronte ligeiramente mais escurecida perto das antenas, mas sem manchas nítidas. Parte posterior da cabeça castanho-avermelhada, ligeiramente mais clara que o tórax, com exceção de uma faixa preta, estreita, transversa, no topo da lâmina cerebral. Pvt e vti rudimentares. Fronte mais estreita que metade da largura da cabeça. Antenas castanho-avermelhadas, a base do terceiro segmento mais clara, tendendo ao amarelo. Arista curta, branca, com base castanha, inserida um pouco adiante da metade do pós-pedicelo.

Tórax, especialmente mesonoto, com polinosidade cinzenta, visivel ou não, conforme o ângulo de observação. Cerdas: 1 ntpl, 1 sa, 1 pa, 1 dc, 1 sc. Tíbias e tarsos, em nítido contraste com o restante das pernas, castanho-amarelados; nas pernas posteriores, essas estruturas são ainda mais claras que nas médias e anteriores. A pilosidade, nessas regiōes, acompanha o colorido do integumento. Tíbias posteriores sem estreitamento pré-apical. Halteres curtos, com haste amarelada e capítulo escuro. Asas hialinas, sem escurecimento apreciável no ápice. 
Vol. 7(3), 1990
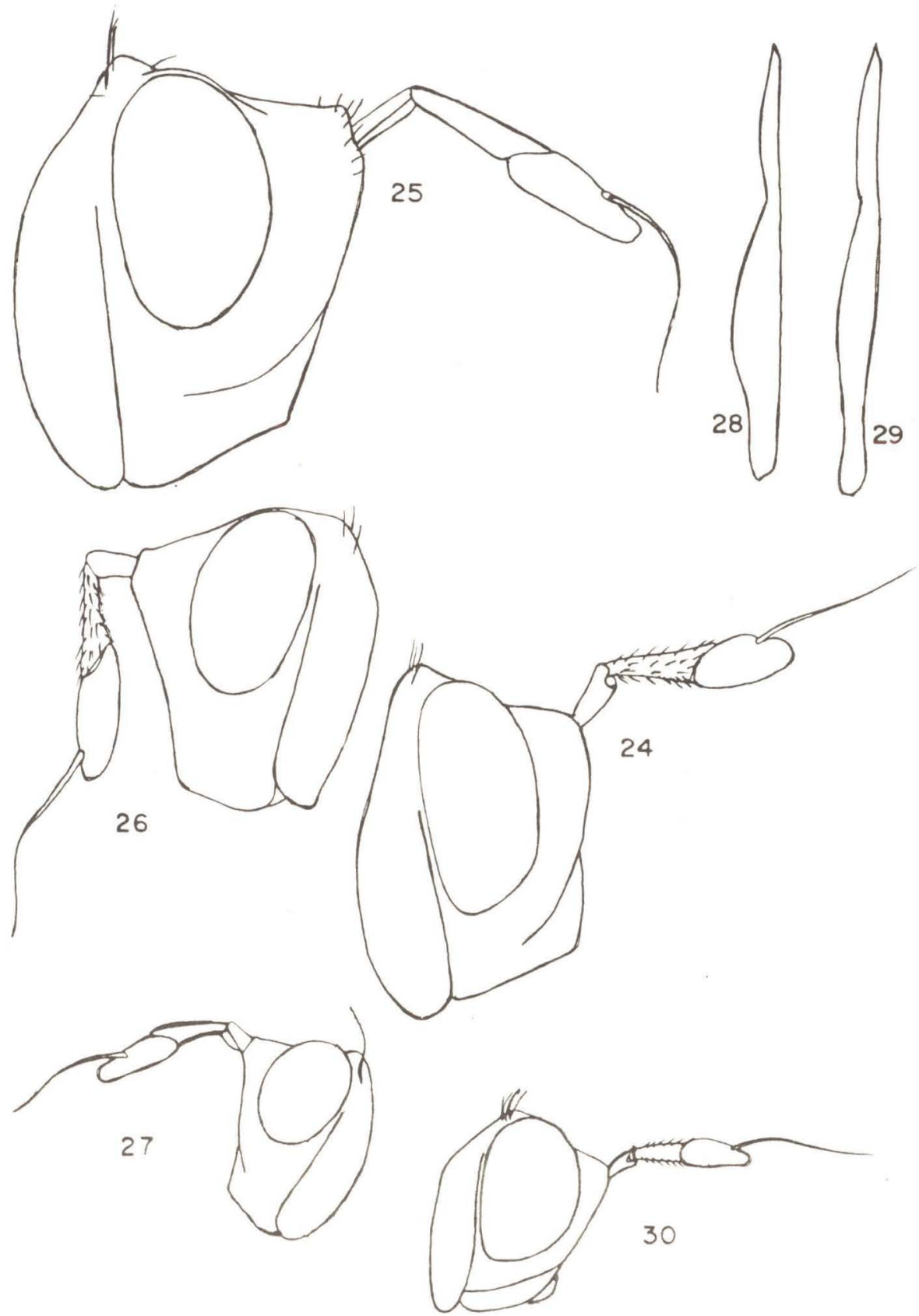

Figuras 24 a 30

Cabeça, vista lateral. 24. flavipes. 25. lenkoi. 26. brevipennis. 27. tibialis. 30. minensis. Tibia. 28, tibialis. 29. minensis. 
Abdome castanho-avermelhadoescuro, bem mais escuro que o resto do corpo. Sintergito com ligeiramente mais que duas vezes o comprimento do $3^{\circ}$. tergito.

Material. BRASIL. São Paulo: Campos do Jordão, 1 ơ (holótipo), XII.1952, L. Travassos Fn

Leptopyrgota lenkoi, sp.n.

(Fig. 25)

Compr. corpo, $14 \mathrm{~mm}$; compr. asa, $13 \mathrm{~mm}$; larg. asa, $4 \mathrm{~mm}$.

Colorido básico do corpo castanho-avermelhado, especialmente nítido no tórax e nas pernas, com as ressalvas a serem feitas adiante.

Com exceção da parte posterior, a cabeça é brilhante. Duas faixas castanho-escuras, de limites pouco nítidas, correm desde os lados das antenas, adjacentes às órbitas, até quase a margem posterior. As manchas infra-oculares expandem-se para o canto inferior das genas, confluindo com uma mancha de limites pouco nítidos que corre pela margem oral até a placa mesofacial. Essas manchas estão ligadas às manchas frontais por uma estreita faixa castanho-escura, esmaecida. A placa mesofacial leva uma mancha redonda, escura, ao pé das antenas e outra, mal visível e mal delimitada, triangular, na margem oral. Pvt e vti presentes, bem visíveis e maiores do que costumeiramente ocorre no gênero. Primeiros dois segmentos antenais castanho-escuros, terceiro castanho-avermelhado, claro. Arista esbranquiçada, longa, com base castanho-avermelhada, aproximadamente no meio da face superior do pós-pedicelo.

Fronte visivelmente mais larga que a metade da largura da cabeça.

Cerdas torácicas: 1 stpl e 1 ptpl longas; 2 ntpl, 1 sa, 2 pa, 1 dc, 2 sc. Halteres castanho-claros, opacos. As pernas médias e posteriores são particularmente avermelhadas até as tíbias. Os tarsos e as extremidades das tíbias posteriores são castanhos, muito escuros, quase negros. Pêlos das pernas também avermelhados ou dourados, mas há pêlos pretos nos tarsos. O estreitamento das tíbias posteriores ocorre quase no meio de seu comprimento; daí em diante, o espessamento é gradual, atingindo duas vezes a espessura da parte basal e, após novo estreitamento mais ou menos abrupto a quatro quintos da base, a tíbia prossegue com espessura mais ou menos uniforme. Asas longas, hialinas, com ligeiro escurecimento no ápice, mas sem mancha nítida e bem demarcada. Pós-escutelo rudimentar, quase ausente. Abdome castanho, mais escuro que o tórax. Sintergito duas vezes e meia mais longo que o 3 . tergito.

\section{V. brevipennis e flavipes}

Material. BRASIL. São Paulo: Barueri, 1 o (holótipo), 23.XII.1956, K. Lenko.

\section{Leptopyrgota brevipennis, sp.n.}

(Fig. 26)

Compr. corpo, $9 \mathrm{~mm}$; compr. asa, 9,5 mm; larg. asa, 3,5 mm.

Cabeça, tórax e pernas, até as tíbias, com integumento castanho-avermelhado, brilhante.

Cabeça com colorido muito uniforme e com as seguintes manchas: uma, esmaecida, abaixo dos olhos, que não atinge o canto da gena; três, muito nítidas, pequenas, redondas, negras, na lâmina mesofacial, uma ao pé das antenas e duas embaixo, laterais, 
encostadas nos bordos da lâmina e separadas da margem oral por distância igưal a seu próprio diâmetro. Cabeça menos que uma vez e meia mais alta que longa. Olhos nitidamente oblíquos, ligeiramente mais altos que metade da altura da cabeça; conseguintemente, genas muito amplas. Primeiros dois segmentos antenais de colorido castanho muito escuro, o terceiro avermelhado, mais escuro em cima e na frente, muito polinoso. Arista clara, suja, com considerável trecho basal largo e castanho, inserida no quarto final do pós-pedicelo. Vt rudimentares, pvt ausentes. Fronte mais estreita que metade da largura da cabeça.

Cerdas torácicas: $1 \mathrm{ntpl}, 1 \mathrm{sa}, 2 \mathrm{pa}, 1 \mathrm{dc}, 1 \mathrm{sc}$. Halteres longos, com haste e capítulo amarelos. Tíbias e tarsọs anteriores e médios ligeiramente mais escuros que o resto das pernas correspondentes. Tarsos posteriores mais claros que o resto das pernas do mesmo par, com pêlos dourados; além disso, bem mais espessos que os tarsos anteriores e médios. O estrangulamento das tíbias posteriores ocorre ao término do terço proximal; daí em diante, o espessamento é gradual e acentuado, até umas três vezes o da base, seguido de ligeiro estreitamento pré-apical.

Asas hialinas; ligeiro escurecimento ântero-apical, apenas esboçado.

Abdome castanho-escuro, brilhante; sintergito duas vezes e meia mais longo que 0 3. tergito.

Espécie semelhante a lenkoi e flavipes.

Material. BRASIL. São Paulo: Barueri, 1 đ' (holótipo), XI.1960, K. Lenko.

\section{Leptopyrgota tibiaiis, sp.n.}

(Figs. 27, 28)

Compr. corpo (sem pós-abdome), $5 \mathrm{~mm}$, compr. oviscapo, $3 \mathrm{~mm}$; compr. asa, $6 \mathrm{~mm}$; larg. asa, $1,5 \mathrm{~mm}$.

Cabeça e tórax de cor castanha, brilhante, sem qualquer marca especial de outra coloração. Cabeça quase uma vez e meia mais alta que longa e ligeiramente mais larga que longa. Os olhos ocupam pouco mais que a metade da altura da cabeça e são ligeiramente oblíquos. Labelos castanhos. Palpos amarelos, com poucos pêlos negros. Antenas com aproximadamente o mesmo comprimento da cabeça; primeiros dois segmentos aproximadamente da cor da cabeça; terceiro opaco, em vista externa castanho-claro na base e escurecendo em direção ao ápice, mas amarelo na parte superior basal interna; arista um pouco maior que o terceiro segmento, grossa na base, depois muito alongada. Cerdas cefálicas visíveis: 1 pvt, 1 vti, todas curtas e negras.

Tórax muito ligeiramente mais escurecido que a cabeça. Mesonoto com pequenos pêlos pretos inclinados para trás. Cerdas torácicas muito reduzidas, as da região alar difíceis de distinguir; o par notopleural é nítido, há $1 \mathrm{sc}$. Escutelo pequeno, pouco saliente. Halteres castanhos, com haste clara e capítulo escuro, opaco. Colorido básico das pernas semelhantes ao do tórax, com ligeiras variações. Fêmures médios, no terço distal, e tíbias médias, na metade distal, com tons castanhoescuros não muito marcados. Fêmures posteriores também escuros no terço apical. Tíbias posteriores com o estreitamento a um terço da base; parte basal muito estreita, a distal excepcionalmente grossa, com espessura máxima de umas três vezes a da parte basal; a parte espessa é castanho-escura no meio, com pêlos da mesma cor. Os artículos terminais de todos os tarsos são mais escuros que o restante das pernas. Asas longas, hialinas, com nervuras castanho-claras; mal distingue-se um ligeiro escurecimento ântero-apical. 
Pré-abdome castanho-escuro, brilhante. Sintergito basal mais de duas vezes mais longo que o $3^{\circ}$. tergito. Oviscapo largo, nitidamente mais longo que o pré-abdome, castanho escuro, mais com aspecto de âmbar.

Esta espécie assemelha-se muito a minuta e minensis. Difere de ambas pela forma alongada da asa, pelo espessamento excepcional das tíbias posteriores e pela ausência de manchas na cabeça; da primeira pela forma da cabeça e da antena (cf. Aczél, fig. 43); da segunda, também pela auséncia de manchas torácicas.

Material. BRASIL Rio de Janeiro: Itatiaia, L. 41, 1300 m, 19 (holótipo), 10-12.X.1950, Travassos, Albuquerque \& Pearson.

\section{Leptopyrgota minensis, sp.n.}

(Figs. 29, 30)

Compr. corpo (sem pós-abdome), $5 \mathrm{~mm}$; compr. oviscapo, $3 \mathrm{~mm}$; compr. asa, $7 \mathrm{~mm}$; larg. asa, $2 \mathrm{~mm}$.

Espécie muito semelhante a tibialis, diferindo no seguinte:

Cabeça e tórax com colorido básico castanho, mas cabeça nitidamente mais escura. Marcas cefálicas de colorido diferencial: uma faixa castanho-escura transversal atrás do vértice, no quarto superior da lâmina cerebral; uma mancha escura abaixo das margens inferiores dos olhos; três pequenas manchas castanho-escuras na placa mesofacial, uma longa abaixo da inserção das antenas, as outras duas, laterais, acima da margem oral. As manchas genais e mesofaciais são mais claras que a mancha pós-vertical. Olhos maiores, ocupando mais de dois terços da altura da cabeça e menos oblíquos. Genas e occipício menores. Palpos castanho-amarelados. Primeiros dois segmentos antenais da cor do integumento œfálico, dois terços basais do terceiro mais claros, castanho-amarelados.

Manchas castanho-escuras no tórax: uma faixa larga central (com uma linha clara no meio) do bordo anterior do mesonoto, seguindo por um quarto de sua extensão, unindo-se com duas manchas laterais, sub-quadrados; após o meio do mesonoto, duas manchas triangulares, quase confluentes no meio, prolongadas em diagonal para os cantos posteriores do mesonoto; faixa na metade anterior da mesopleura; manchas mais claras na metade inferior da esternopleura e da hipopleura; escutelo também castanhoescuro; duas manchas laterais nos dois terços inferiores do mediotergito, confluentes embaixo. Fêmures médios ligeiramente mais escuros na metade apical. Fêmures posteriores mais escuros a partir do segundo terço. Tibias posteriores sem espessamento excepcional e sem escurecimento. Asas mais largas.

Oviscapo castanho-claro, em nítido contraste com o pré-abdome.

Em comparação com a ilustração da asa de minuta (Aczél, pl. 3, fig. K), a asa de minensis não parece tão escura em direção ao ápice e tem a célula anal mais estreita e com limite anterior mais redondo.

Material. BRASIL. Minas Gerais: Pouso Alegre, 1 १ (holótipo), I.1946, Pe. Pereira.

\section{Leptopyrgota caelifera, sp.n.}

Compr. corpo, $15 \mathrm{~mm}$; compr. asa, $15 \mathrm{~mm}$; larg. asa, 4,5 mm.

Cabeça castanho-clara, ligeiramente avermelhada na fronte, genas e lâminas mesofacial, e amarelada atrás. Manchas infra-oculares alongadas, quase atingindo a margem oral. Manchas da lâmina mesofacial pequenas: uma ao pé das antenas, arredondadas, 


\section{Vol. 7(3), 1990}

duas subtriangulares um pouco acima da margem oral. Na fronte, uma mancha castanha grande, arredondada, ocupa metade do comprimento frontal. Primeiro e segundo segmentos antenais castanho-escuros, com pêlos castanhos, o terceiro mais claro, avermelhado. Arista longa, com base castanha muito escura, depois amarelada. Em vista lateral, a cabeça é quase vez e meia tão alta quanto longa. Os olhos ocupam mais da metade da altura da cabeça e são ligeiramente oblíquos. A cabeça é um pouco mais larga que longa e a fronte é consideravelmente divergente para a frente. 1 pvt, curtas; 2 vti, uma logo após a outra, maiores que as pvt.

Tórax castanho-amarelado, claro, sujo, com matizes mais escuros na metade anterior da mesopleura e adiante das coxas médias e posteriores. $\mathrm{O}$ mesonoto apresenta as manchas escuras comuns no gênero, mas mal demarcadas e pouco nítidas. 0 mediotergito é castanho no bordo inferior e em grande extensão abaixo do escutelo; entre as duas áreas mencionadas, é amarelo. Halteres castanho-avermelhados. Cerdas torácicas curtas: $1 \mathrm{mspl}, 1 \mathrm{ptpl}, 2 \mathrm{pa}$ ( 1 forte), $1 \mathrm{sc}$ (forte). Pernas castanho-avermelhadas, os tarsos nitidamente mais escuros. A mancha apical da asa é nítida, mas curta, chegando tão somente a pouco mais da metade da distância entre o ápice e a altura da transversal posterior, ao contrário do que ocorre em costalimai, em que a mancha se alonga até praticamente a transversal anterior.

Abdome peciolado no sintergito, mas mais curto que em costalimai. Sintergito mais de duas vezes mais longo que o 3 . tergito. Tergitos castanho-amarelados, claros, com matizes castanho-escuros nos lados da metade basal do sintergito e, transversalmente, na metade distal dos 3 ? e 4 ? tergitos. 0 último tergito é subquadrado, ao passo que em costalimai é visivelmente mais longo que largo. A cor dos esternitos é a mesma dos tergitos. Nas extremidades dos três últimos tergitos, há longos pêlos negros.

Esta espécie, superficialmente, é muito semelhante a costalimai, mas difere no seguinte: mancha apical da asa mais curta; abdome mais curto e claro; tamanho menor; manchas cefálicas diferentes; olhos mais oblíquos; coloração com detalhes diversos; tarsos mais grossos.

Material. BRASIL To Paulo: Itu, Fazenda Pau d'Alho, 1 of(holótipo), 1-5.XI.1961, Martins, Kloss \& Silva.

\section{Leptopyrgota hesterna, sp.n.}

Compr. corpo, $10 \mathrm{~mm}$; compr. asa, $11 \mathrm{~mm}$; larg. asa, $3 \mathrm{~mm}$.

A cabeça do holótipo está um pouco deformada, comprimida na placa mesofacial, que parece ter sido empurrada para dentro da cabeça; as antenas ficaram parcialmente escondidas. Isso prejudiça um pouco a descrição dessa região.

Fronte castanho-avermelhada, com matiz mais escuro atrás. Entretanto, a margem posterior e as laterais (bordeando os olhos), todas estreitas, são amareladas. A cor das margens laterais prossegue para a frente, ao lado das antenas e da placa mesofacial, até a margem oral. Há uma mancha escura nítida abaixo dos olhos; abaixo dela, um escurecimento castanho mal definido. Logo atrás das genas, o occipício é amarelo, mas na maior parte de sua extensăo, atrás da cabeça, é castanho-negro, exceto um triângulo superior mais claro, atrás do vértice. Lâmina mesofacial da mesma cor da face, com duas manchas escuras oblongas pouco acima da margem oral; presumivelmente, uma mancha ao pé das antenas. Primeiros dois segmentos antenais castanho-escuros, quase negros, terceiro castanho-avermelhado na metade proximal, escuro na distal. Arista amarelada, longa, com base escura inserida pouco além do meio da margem superior do pós-pedicelo. Palpos e 
labelos castanho-amarelados, claros. Cabeça cerca de vez e meia mais alta que longa e mais de duas vezes mais larga que longa. Fronte larga, mas não tanto quanto metade da largura da cabeça. Um par de pós-verticais mais longas que o comum no gênero, divergentes, e um par de verticais internas, mais longas que as pós-verticais.

Tórax de colorido uniforme, castanho-negro, com polinosidade cinzenta, mais concentrada na esternopleura e formando padrão no mesonoto: duas faixas estreitas dorsocentrais, começando no bordo anterior e terminando um pouco atrás da metade; duas faixas laterais, longitudinais, mais largas que as outras, começando na altura dos lobos umerais, interrompendo-se na sutura e prosseguindo para trás, mas sem atingir o término do mesonoto. Cerdas torácicas longas e fortes: $1 \mathrm{stpl}, 1 \mathrm{mspl}, 2 \mathrm{ntpl}, 1 \mathrm{sa}, 2 \mathrm{pa}, 1 \mathrm{sc}$. Halteres amarelos. Pernas castanho-claras até os fêmures. Tíbias anteriores e médias castanho-escuras. Tíbias posteriores, em quatro quintos de sua extensão, também castanhoescuras, mais vivas que as outras, mas catanho-negras no quinto distal. Essa é também a cor dos tarsos posteriores e dos quatro artículos finais dos médios e anteriores. $\mathrm{O}$ fêmur anterior é bem espessado no meio e o posterior um pouco espessado a uns três quartos de sua extensão. Tarsos posteriores nitidamente mais grossos que nos outros. Tíbias posteriores com estrangulamento a um terço da base, depois bastante espessadas, pelo menos umas duas vezes mais que o terço proximal. Asas hia' nas; a custo, vê-se um início de escurecimento no ápice. Transversal anterior no meio da discal.

Abdome curto, castanho muito escuro no sintergito e claro nos outros tergitos. Sintergito três vezes mais longo que o $33^{\text {O }}$. tergito.

Material. BRASIL. Såo Paulo: Campos do Jordão, $1 \sigma$ (holótipo), I.1953, L. Travassos Fo.

\section{REFERÊNCIAS}

ACZÉL, M. 1956. Revision parcial de las Pyrgotidae neotropicales y antárcticas con sinopsis de los géneros y especies (Diptera, Acaly ptratae). Rev . bras. Ent. 4:161-184, 5:1-70, 6:1-38.

STEYSKAL, G.C. 1967. Family Pyrgotidae, in Museu de Zoologia, Universidade de São Paulo, A catalogue of the Diptera of the Americas south of the United States 56:1-8. 